\title{
Effect of Fosamax on the Duodenal Mucosa in Adult Male Albino Rats and the Possible Protection by Nigella Sativa Oil: A Histological and Immunohistochemical Study
}

\author{
Amira Adly Kassab
}

Department of Histology, Faculty of Medicine, Tanta University, Egypt

\begin{abstract}
Background: Fosamax, an oral bisphosphonate, is the most commonly prescribed drug for the treatment of various bones diseases. However, Fosamax therapy is associated with gastrointestinal toxicity that influences the treatment compliance. Nigella sativa ( $\mathrm{N}$ sativa) is an annual herbaceous plant and have been safely used as a natural remedy in Egypt. It has a wide range of pharmacological activities and a proposed role in combating many gastrointestinal disorders.

Aim: This work aimed to study the effect of Fosamax on the histological structure of the duodenal mucosa of albino rats and to evaluate the possible protective role of nigella sativa oil.

Materials and methods: Forty adult male albino rats were divided into four equal groups: the control group, the $\mathrm{N}$ sativa oil-treated group $(2.5 \mathrm{ml} / \mathrm{kg})$, the Fosamax-treated group $(0.05 \mathrm{mg} / \mathrm{kg})$, and both Fosamax and $\mathrm{N}$ sativa oil -treated group. Treatments were given orally once weekly for 13 weeks. Specimens from the duodenum were processed for light microscopy. Immunohistochemical study was carried out using antibodies against nuclear factor- $\kappa \mathrm{B}(\mathrm{NF}-\kappa \mathrm{B})$, cyclooxygenase-2 (COX-2), B-cell lymphoma 2 (Bcl-2), Bcl-2-associated X protein (Bax) and Ki67 protein.

Results: Specimens from Fosamax-treated rats showed a statistically significant decrease in the duodenal mucosal thickness. The lining epithelium showed nuclear alteration and vacuolated cytoplasm and there was mononuclear cellular infiltration. The immunohistochemical study of Fosamax-treated group showed a significant increase in NF-kB, COX-2 and Bax immunoreaction and a significant decrease in Bcl-2 and Ki67 expression. In contrast, minimal changes were observed in rats treated concomitantly with both Fosamax and $\mathrm{N}$ sativa oil with non-significant changes in the immunoreactions compared with the control group.

Conclusion: Fosamax induced structural changes in the duodenal mucosa of adult albino rats, which could be ameliorated by concomitant treatment with nigella sativa oil.
\end{abstract}

Received: 24 March 2019, Accepted: 03 June 2019

Key Words: Duodenal mucosa, fosamax, nigella sativa oil.

Corresponding Author: Amira Adly Kassab, MD, Department of Histology, Faculty of Medicine, Tanta University, Egypt, Tel.: +20 1229449293, E-mail: amirakassab80@yahoo.com

ISSN: 1110-0559, Vol. 42, No. 4

\section{INTRODUCTION}

Bisphosphonates are the first-line therapy to prevent fractures in various diseases that are associated with bone resorption such as postmenopausal osteoporosis and Paget's disease of bone. They are classified into non-nitrogen containing bisphosphonates as etidronate and the more potent nitrogen containing bisphosphonates as alendronate. Fosamax is one of the nitrogen containing bisphosphonates that is composed mainly of alendronate. The exact mechanism of action has been revealed for both types. The non-nitrogen containing bisphosphonates produce cytotoxic ATP analogues which prevents the mitochondria from functioning properly inducing osteoclast apoptosis. In contrast, the nitrogen containing bisphosphonates inhibit the enzymes regulating the mevalonic acid pathway interfering with small GTPases needed for bone resorption by osteoclasts ${ }^{[1,2]}$.
The most commonly reported adverse effects due to the oral intake of bisphosphonates are dyspepsia, dysphagia, nausea, vomiting, upper abdominal pain and discomfort ${ }^{[3]}$. Fosamax intake may be associated also with gastrointestinal events as erosive esophagitis, gastritis, duodenitis, ulceration, stricture and gastrointestinal perforation. Moreover, hemorrhage due to esophageal, gastric, duodenal or peptic ulcers may occur ${ }^{[4,5,6,7]}$.

It has been reported that bisphosphonates differ in their potential to damage the mucosa, alendronate having a higher potential for such effect. It was reported that the rate of acute mucosal injury due to alendronate was comparable with that observed with non-steroidal anti-inflammatory drugs. The gastrointestinal side effects were attributed to high local concentrations of the drug in patients who did not follow the recommended proper dose. Although the adverse effects of bisphosphonates on the gastrointestinal 
system have been demonstrated in many experimental and clinical studies, the exact mechanisms underlying this mucosal damage are not clear yet ${ }^{[8,9,10,11]}$.

In recent years, there is a growing interest in the use of natural products, especially those derived from plants. Nigella sativa Linn (N sativa) is an annual herb commonly known as black seed or black cumin from the botanical family of Ranunculaceae. It contains more than $30 \%$ of fixed oil and $0.4-0.45 \%$ of volatile oil that contains $18.4-24 \%$ thymoquinone. The oil extracted from $\mathrm{N}$ sativa is mostly consisted of linoleic acid, oleic, dihomolinoleic acid, palmitic acid, stearic acid, myristic acid, stroles and eicodadienoic acid. It plays an important role in prevention of many diseases due to its anti-cancer, hepatoprotective, anti-bacterial, anti-inflammatory and antioxidant activities $^{[12,13]}$

Previous studies illustrated the protective and therapeutic role of $\mathrm{N}$ sativa oil in various gastrointestinal disorders involving mucosal injury and cancers ${ }^{[14,15,16]}$. Subsequently, the present research aimed to study the effect of Fosamax on the histological structure of the duodenal mucosa in adult male albino rats and to evaluate the possible protective role of nigella sativa oil using different histological and immunohistochemical techniques.

\section{MATERIALS AND METHODS}

\section{Chemicals}

1. Fosamax ${ }^{\circledR}$ tablets. It contains alendronate sodium which is the active ingredient of Fosamax. Each tablet contains $91.37 \mathrm{mg}$ of alendronate (Merck and Co. Inc., USA; Reg. No. 195/2014).

2. Nigella sativa oil: a glass bottle $(30 \mathrm{ml})$ manufactured by El Captain Company for extracting natural oils, plants and cosmetics (Cap Pharm, Egypt).

\section{Study design}

The procedures of this study were approved by the Local Ethics Committee of Faculty of Medicine, Tanta University, Egypt (Approval code: 32666/10/18). Forty adult male albino rats were used in this study; each of them weighs from 200-240 grams. All animals were kept in clean properly ventilated cages with free access to a balanced laboratory diet and water. They were acclimatized for 2 weeks before the experiment.

\section{The animals were divided into four equal groups (ten animals each)}

Group I (control group): It was subdivided into two equal subgroups; subgroup Ia received no treatment. Subgroup Ib received $0.5 \mathrm{ml}$ of normal saline solution (the vehicle for Fosamax) orally once weekly for 13 weeks.

Group II (N sativa oil-treated group): Rats of this group were administered $2.5 \mathrm{ml} / \mathrm{kg}$ of $\mathrm{N}$ sativa oil orally once weekly for 13 weeks ${ }^{[17]}$.
Group III (Fosamax-treated group): Rats of this group were administered $0.05 \mathrm{mg} / \mathrm{kg}$ of Fosamax dissolved in 0.5 $\mathrm{ml}$ of normal saline solution orally by a gastric tube once weekly for 13 weeks. The Fosamax dose was calculated according to the usual human dose $\mathrm{e}^{[18]}$.

Group IV (Fosamax and N sativa oil-treated group): Rats of this group were administered $\mathrm{N}$ sativa oil one hour before Fosamx administration (at the same doses and duration as in groups II andIII, respectively).

At the end of the experiment, the rats were anaesthetized by an intraperitoneal injection of pentobarbital in a dose of $50 \mathrm{mg} / \mathrm{kg}^{[19]}$. A midline incision was done through the anterior abdominal wall. The duodenum of each rat was carefully removed and was flushed with normal saline to clean its interior.

For histological study, the samples were fixed in $10 \%$ neutral buffered formalin for routine histological paraffin embedding. Sections of $5 \mu \mathrm{m}$ thickness were stained with the routine hematoxylin and eosin (HandE $)^{[20]}$, and Periodic Acid Schiff (PAS) reaction ${ }^{[21]}$ and examined by the light microscope.

For immunohistochemistry, $5 \mu \mathrm{m}$-thick duodenal sections were deparaffinized, rehydrated, and washed in phosphate buffered saline (PBS). Then, the sections were incubated overnight at $4^{\circ} \mathrm{C}$ in a humid chamber with the following primary antibodies; (rabbit polyclonal anti-rat antibody against the P65 subunit of NF- $\mathrm{KB}, 1: 20$ dilution, ab86299, Abcam), (rabbit polyclonal antibody against COX-2, 1:100 dilution, ab15191, Abcam), (rabbit polyclonal antibody against Bcl-2, 1:100 dilution, ab59348, Abcam), (rabbit polyclonal antibody against Bax, 1:50 dilution, ab53154, Abcam) and (rabbit polyclonal anti-rat antibody against Ki67, 1:1000 dilution, ab15580, Abcam, Cambridge, Massachusetts, USA) in PBS. Thereafter, it was washed in PBS buffer and co-incubated with biotinylated secondary antibody for an hour at the room temperature. Streptavidin peroxidase was added for ten minutes and rinsed three times in PBS. The immunoreactivity was visualized using 3, 3'diaminobenzidine (DAB)hydrogen peroxide as a chromogen. Sections were counterstained with Mayer's haematoxylin. The negative control sections were prepared without using the primary antibodies ${ }^{[22]}$. Positive controls were breast carcinoma, lung adenocarcinoma and ovarian carcinoma for NF$\kappa \mathrm{B}$; mouse brain, rat hippocampus and human breast carcinoma tissue for COX-2; human colon carcinoma tissue for Bcl-2; human lung carcinoma tissue and human gallbladder tissue for Bax; mouse and human spleen tissue for Ki67. NF-кB-immunostained duodenal sections were considered positive upon expressing clear evident brown nuclear and/or perinuclear cytoplasmic coloration. The Bcl-2-immunostained duodenal sections were considered positive upon expressing clear evident brown cytoplasmic coloration. The COX-2 and Bax-immunostained duodenal sections were considered positive upon expressing clear evident brown cytoplasmic and/or nuclear coloration. The 
Ki67 immunostained duodenal sections were considered positive upon expressing clear evident brown nuclear coloration.

\section{Morphometric study}

Image analysis system (Leica Qwin $500 \mathrm{C}$ Image analyzer computer system, Leica Imaging System LTD., Cambridge, England) at Central Research Lab, Faculty of Medicine, Tanta University, Egypt was used to measure:

1. The thickness of the duodenal mucosal layer at four different sites in each HandE-stained section at a magnification of 200 and the average was taken. Furthermore, four well-aligned villi and their corresponding crypts were measured for villi height and crypt depth.

2. Goblet cell number in the duodenal mucosa (in PASstained sections): four different non-overlapping randomly-selected fields at magnification of 400 were examined for each slide.

3. Area percentage for PAS positive reaction (in PASstained slides): Four different non-overlapping randomly-selected fields at magnification of 400 were examined for each slide.

4. Area percentages (area \%) for NF- $\kappa \mathrm{B}, \mathrm{COX}-2$ and Bcl-2 positive immunoreaction (in DAB-stained slides). Four different non-overlapping randomlyselected fields at magnification of 400 were examined for each slide.

5. Epithelial cell apoptotic index (AI) and proliferative index (PI): The number of Bax and $\mathrm{Ki}-67$-positive epithelial cells was counted in Bax and Ki67-immunostained sections respectively at a magnification of 1000 . The results were expressed as a percentage of the total number of cells counted in the epithelium (number of labeled cells $\times 100$ / total cell number).

\section{Statistical analysis}

Data analysis was carried out by one-way analysis of variance (ANOVA)followed by Tukey's test for comparison between the groups using statistical package for social sciences statistical analysis software (version 11.5; SPSS Inc., Chicago, Illinois, USA). The mean value \pm standard deviation (Mean $\pm \mathrm{SD}$ ) was determined. Differences were regarded as significant if probability value $p<0.05^{[23]}$.

\section{RESULTS}

No animal deaths were reported throughout the experiment.

\section{Histological results}

\section{1-HandE-staining}

Group I (control group): All control subgroups showed the same histological findings. HandE-stained sections of this group showed the characteristic histological structure of the duodenum that was formed of four organized layers; mucosa, submucosa, musculosa and serosa. The mucosa was formed of epithelium, lamina propria and muscularis mucosa. The mucosa showed numerous elongated villi with a core of connective tissue of the lamina propria with crypts between their bases. The epithelium covering the villi was simple columnar with goblet cells and was continuous with that of the crypts. The lamina propria was composed of loose connective tissue underlying the epithelium and contained the crypts. The muscularis mucosa was formed of smooth muscle fibers that separated the mucosa from the underlying Brunner's glands of the submucosa (Figures 1a and 1b).

Group II (N sativa oil-treated group): The duodenal specimens of this group showed the same histo $\neg$ logical structure of the control group.

Group III (Fosamax-treated group): Examination of HandE-stained sections of Fosamax-treated rats showed multifocal structural changes in the duodenal mucosa. Focal areas showed an apparent decrease in the villi length and crypt depth (Figure 2a). Other areas showed marked destruction and loss of some intestinal villi as well as crypts with sloughing of their epithelial cells (Figures 2b and 2c). Many epithelial cells showed cytoplasmic vacuolation and deeply stained pyknotic nuclei (Figure 2d). The lamina propria showed marked infiltration with numerous mononuclear inflammatory cells and severe congestion of the blood vessels (Figures 2e and 2f).

Group IV (Fosamax and N sativa oil-treated group): HandE-stained sections of this group showed intact mucosal layer with well oriented villi and crypts, almost similar to that of the control group. Nevertheless, a few epithelial cells still showed vacuolated cytoplasm and pyknotic nuclei. Moreover, mild congestion of blood vessels and a few mononuclear cells were detected in the lamina propria (Figures $3 a$ and $3 b$ ).

\section{2-PAS-staining}

PAS-stained duodenal sections from the control group I as well as $\mathrm{N}$ sativa oil-treated group II showed an intense positive reaction in the apical part of numerous goblet cells and the brush border over the villi. Sections from Fosamaxtreated group showed a weak PAS-positive reaction in many goblet cells and the brush border, whereas sections from the Fosamax and $\mathrm{N}$ sativa oil-treated group revealed a moderate reaction in some goblet cells and the brush border (Figures 4, 5 and 6).

\section{Immunohistochemical results}

Nuclear factor $\kappa \mathrm{B}$ antigen immunostaining: In the NF- $\kappa B$-immunostained duodenal sections of the control group (group I) as well as $\mathrm{N}$ sativa oil-treated group II, a few epithelial cells of the mucosa exhibited a weak positive brown nuclear and/or perinuclear cytoplasmic immunoreaction for NF- $\kappa \mathrm{B}$ (Figure 7). In the Fosamaxtreated group (group III), many epithelial cells expressed 
a strong positive nuclear and/or perinuclear cytoplasmic immunoreaction for NF- $\mathrm{KB}$ (Figure 8), whereas the Fosamax and $\mathrm{N}$ sativa oil-treated group (group IV) showed a moderate positive nuclear and/or perinuclear cytoplasmic immunoreaction for NF- $\mathrm{KB}$ only in some epithelial cells (Figure 9).

COX-2 immunostaining: COX-2-immunostained duodenal sections of group I (control group) as well as $\mathrm{N}$ sativa oil-treated group II showed a weak positive brown cytoplasmic immunoreaction in a few epithelial cells of the mucosa (Figure 10). In the Fosamax-treated group (group III), a strong positive cytoplasmic and/or nuclear immunoreaction for COX-2 was observed in many epithelial cells (Figure 11), whereas in the Fosamax and $\mathrm{N}$ sativa oil-treated group (group IV), a moderate positive cytoplasmic and/or nuclear immunoreaction for COX-2 was detected only in some epithelial cells of the mucosa (Figure 12).

Bcl2 antigen immunostaining: Bcl2-immunostained duodenal sections of the control group (group I) as well as $\mathrm{N}$ sativa oil-treated group II showed a strong positive cytoplasmic immunoreaction for $\mathrm{Bcl} 2$ in many epithelial cells of the mucosa (Figure 13). Fosamax-treated group (group III) showed that many epithelial cells expressed a weak positive cytoplasmic immunoreaction for Bcl2 (Figure 14), while the Fosamax and N sativa oiltreated group (group IV) expressed a moderate positive cytoplasmic immunoreaction for Bcl2 in some epithelial cells of the mucosa (Figure 15).

Bax antigen immunostaining: Bax-immunostained duodenal sections of the control group (group I) as well as $\mathrm{N}$ sativa oil-treated group II showed a weak positive brown cytoplasmic and/or nuclear reaction in a few epithelial cells of the mucosa (Figure 16). In Fosamax-treated group (group III), a strong positive cytoplasmic and/or nuclear reaction for Bax was observed in many epithelial cells (Figure 17), while in the Fosamax and N sativa oil-treated group (group IV), a moderate positive cytoplasmic and/ or nuclear reaction for Bax was detected only in some epithelial cells (Figure 18).

Ki67 antigen immunostaining: In the Ki67immunostained duodenal sections of the control group (group I) as well as N sativa oil-treated group II, numerous epithelial cells in the crypts exhibited a strong positive brown nuclear immunoreaction for Ki67 (Figure 19). In the Fosamax-treated group (group III), many epithelial cells expressed a weak positive nuclear immunoreaction for Ki67 (Figure 20), whereas the Fosamax and N sativa oil-treated group (group IV) showed a moderate positive nuclear immunoreaction for Ki67 only in some epithelial cells of the crypts (Figure 21).

\section{Morphometric and statistical results}

The mean duodenal mucosal thickness, villi height, crypt depth and goblet cell number showed a statistically significant decrease in the Fosamax-treated group (Group III) compared to the control group. Moreover, Fosamax and $\mathrm{N}$ sativa oil-treated group (group IV) showed a non-significant decrease compared to the control (Table 1).

The mean area percentage of PAS positive reaction in the Fosamax-treated group (Group III) showed a significant decrease compared to the control group, while Fosamax and $\mathrm{N}$ sativa oil-treated group (group IV) showed a nonsignificant decrease compared to control group (Table 2).

The mean area percentage of NF- $\mathrm{KB}$ and COX-2positive immunoreaction in Fosamax-treated group (Group III) showed a statistically significant increase compared with the control group. Moreover, the Fosamax and N sativa oil-treated group ([group IV) showed a nonsignificant increase compared with the control (Table 2).

The mean area percentage of Bcl2-positive immunoreaction in the Fosamax-treated group (Group III) showed a statistically significant decrease compared to the control group, whereas the Fosamax and $\mathrm{N}$ sativa oil-treated group (group IV) showed a nonsignificant decrease compared with the control (Table 2).

The mean apoptotic index (AI) showed a statistically significant increase in the Fosamax-treated group (group III) compared to the control group. Moreover, the Fosamax and N sativa oil-treated group (group IV) showed a non-significant increase compared to the control group (Table 2).

The mean proliferative index (PI) showed a statistically significant decrease in the Fosamax-treated group (group III) compared to the control group. Moreover, the Fosamax and N sativa oil-treated group (group IV) showed a non-significant decrease compared to the control group (Table 2).

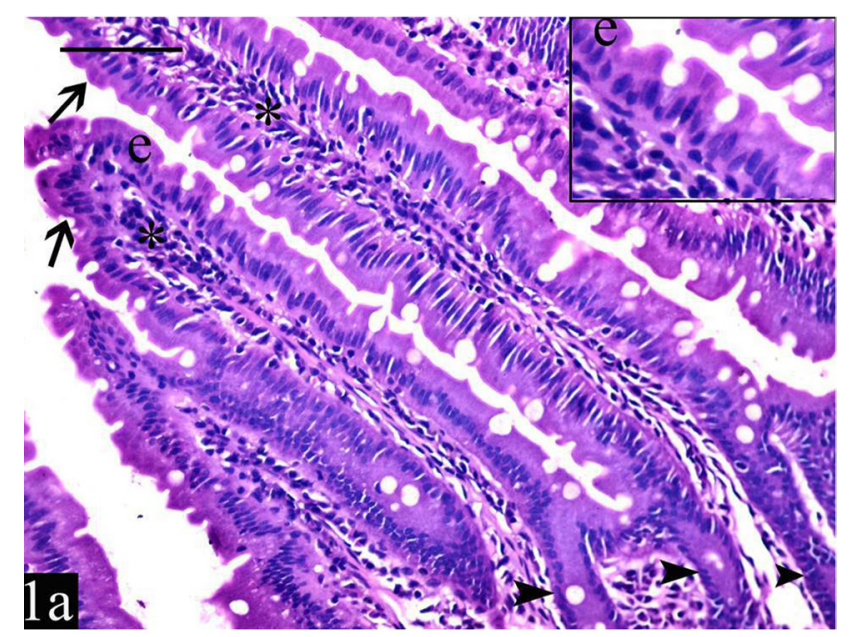

Fig. 1a: A photomicrograph of a section in the duodenal mucosa of an adult albino rat from the control group showing numerous elongated villi (arrow) having a core of connective tissue of the lamina propria (*) with crypts (arrow head) between their bases. The inset shows a higher magnification of the epithelium (e) of the villi (simple columnar with goblet cells). (HandE X400, Inset X1000; Scale bar $=50 \mu \mathrm{m}$ ). 


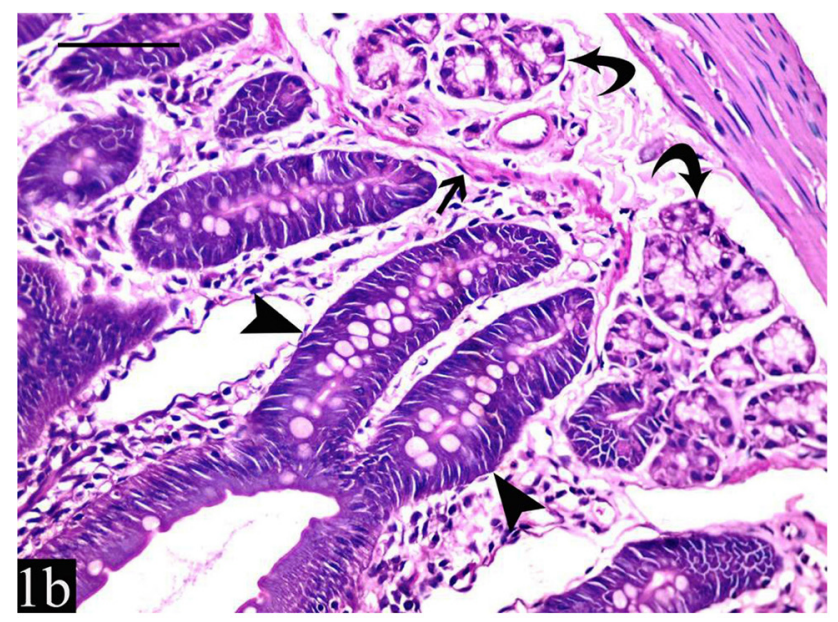

Fig. 1b: A photomicrograph of a section in the duodenum of an adult albino rat from the control group showing the muscularis mucosa (arrow) separating the crypts (arrow head) of the mucosa from the underlying Brunner's glands (curved arrow) of the submucosa. (HandE X400; Scale bar $=50 \mu \mathrm{m})$.

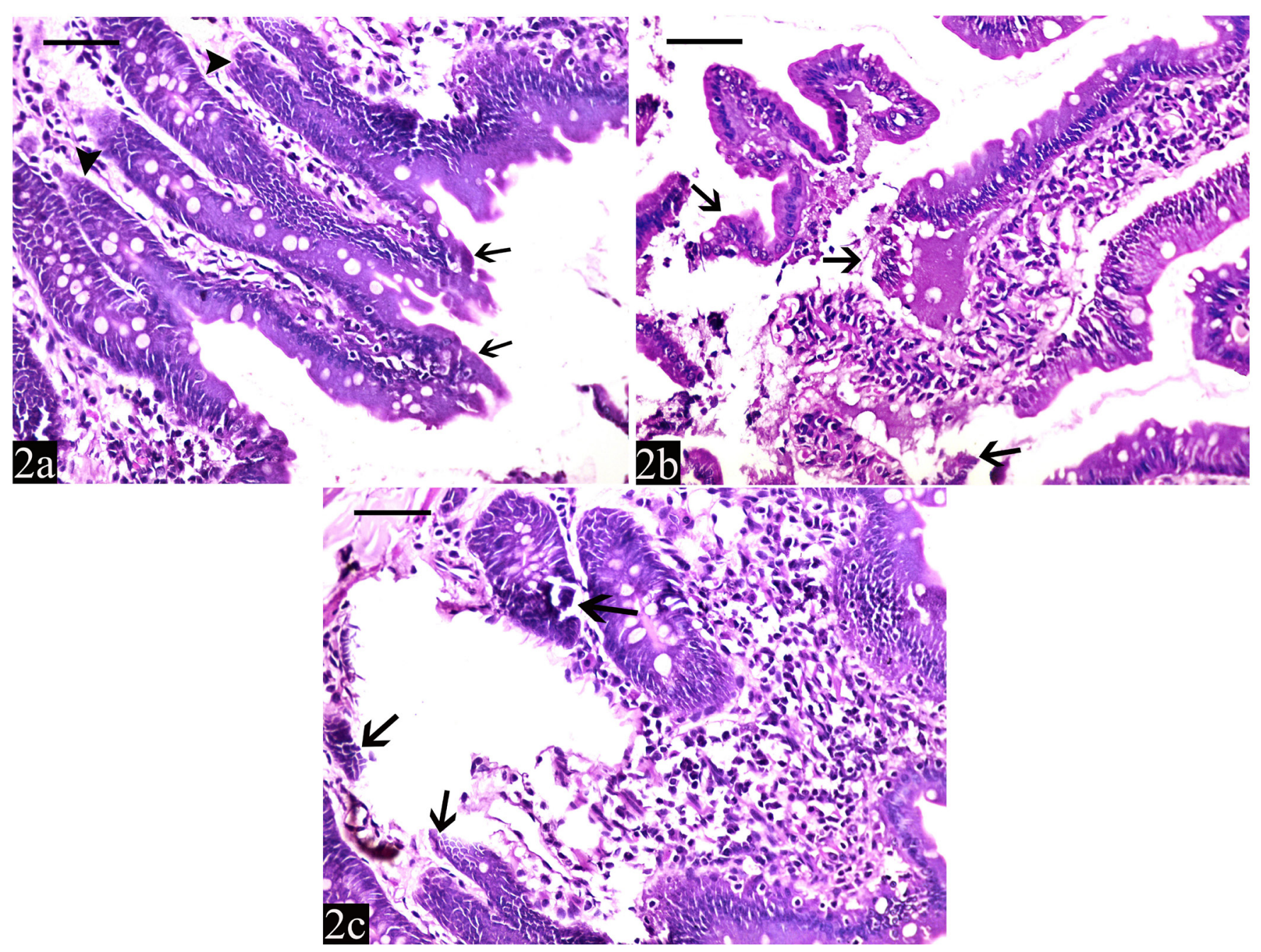

Fig. 2a, 2band2c: Photomicrographs of a section in the duodenal mucosa of an adult albino rat from the Fosamax-treated group (group III) showing an apparent decrease in the villi length (arrow) and crypt depth (arrow head) (a), marked destruction and loss of some intestinal villi (b) and crypts (c) with sloughing of their epithelial cells (arrow). (HandE X400; Scale bar $=50 \mu \mathrm{m}$ ). 


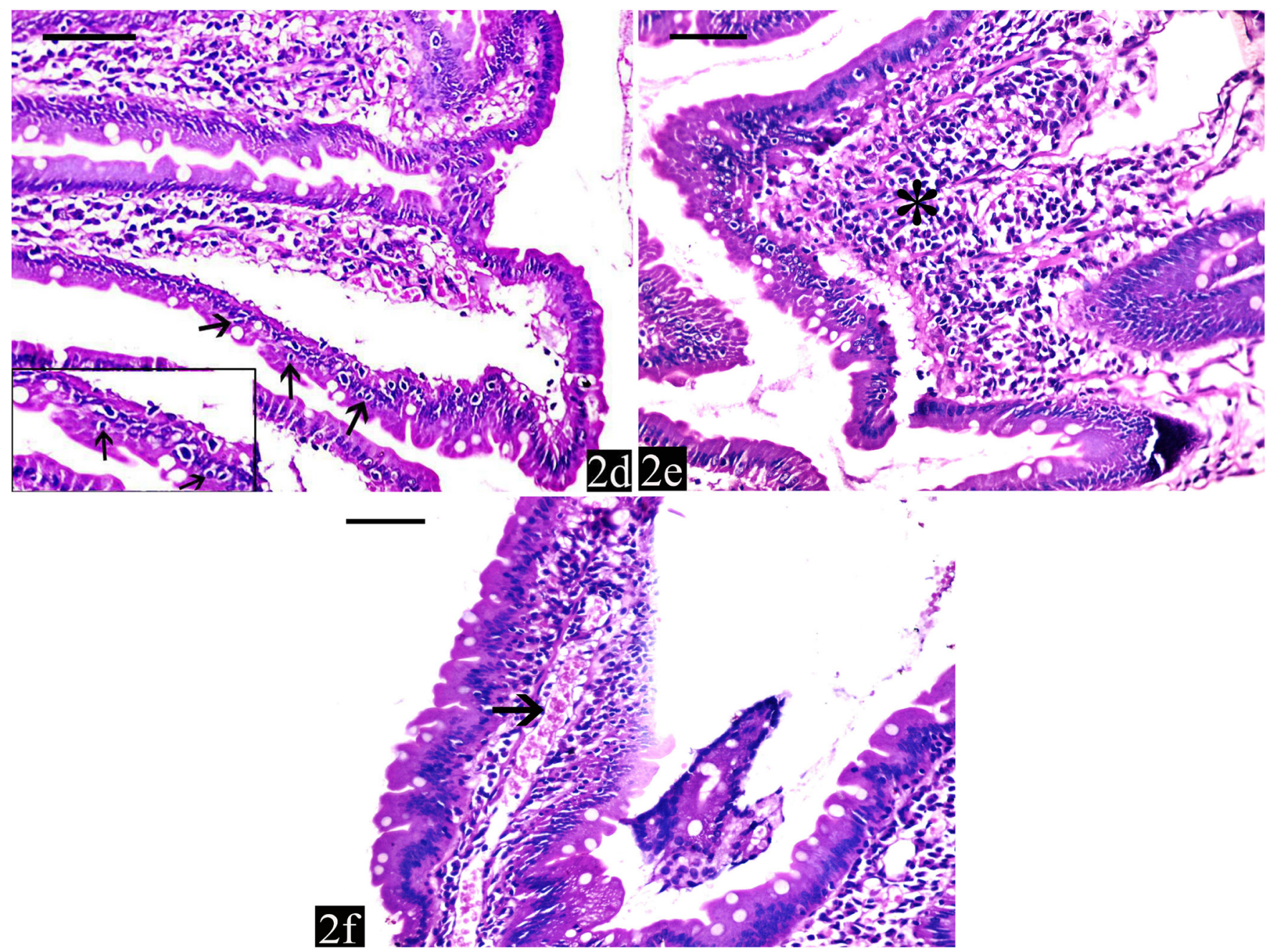

Fig. 2d, 2eand2f: Photomicrographs of a section in the duodenal mucosa of an adult albino rat from the Fosamax-treated group (group III) showing cytoplasmic vacuolation and deeply stained pyknotic nuclei (arrow) of many epithelial cells (d), marked infiltration $(*)$ with mononuclear inflammatory cells (e) and severe congestion (arrow) of the blood vessels (f). The inset shows a higher magnification of the vacuolated epithelial cells (d). (HandE X400, Inset X1000; Scale bar $=50 \mu \mathrm{m})$.

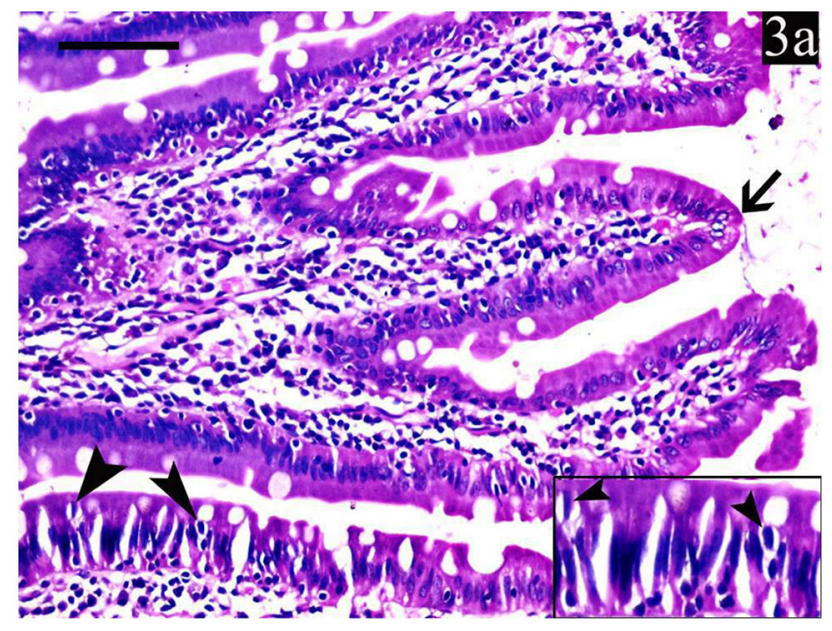

Fig. 3a: A photomicrograph of a section in the duodenal mucosa of an adult albino rat from the Fosamax and $\mathrm{N}$ sativa oil-treated group (group IV) showing well oriented villi (arrow) and a few vacuolated epithelial cells with pyknotic nuclei (arrow head). The inset shows a higher magnification of the vacuolated epithelial cells. (HandE X400, Inset $\mathrm{X} 1000 ;$ Scale bar $=50 \mu \mathrm{m})$

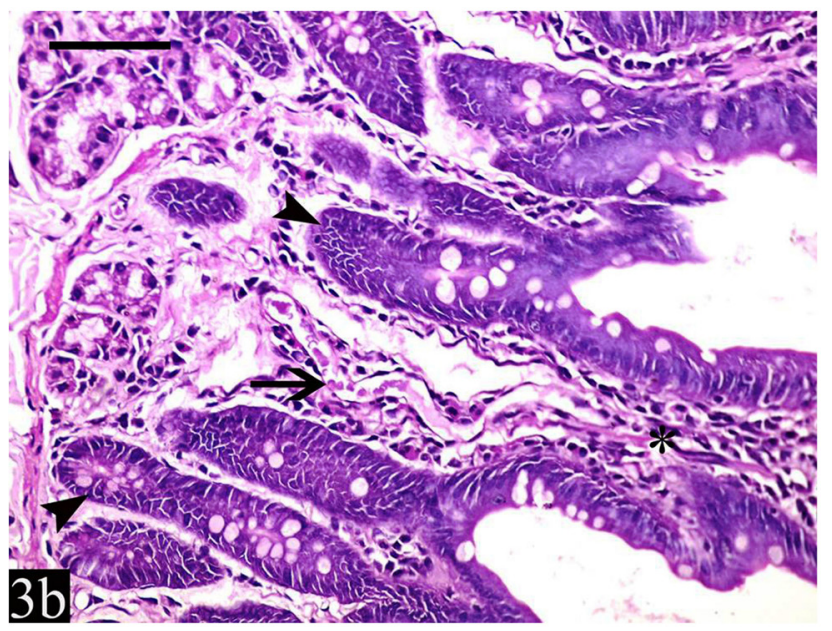

Fig. 3b: A photomicrograph of a section in the duodenal mucosa of an adult albino rat from the Fosamax and $\mathrm{N}$ sativa oil-treated group (group IV) showing crypts (arrow head) in the lamina propria with a few mononuclear cells $(*)$ and mild congestion of the blood vessels (arrow) in between. (HandE X400; Scale bar $=50 \mu \mathrm{m})$. 


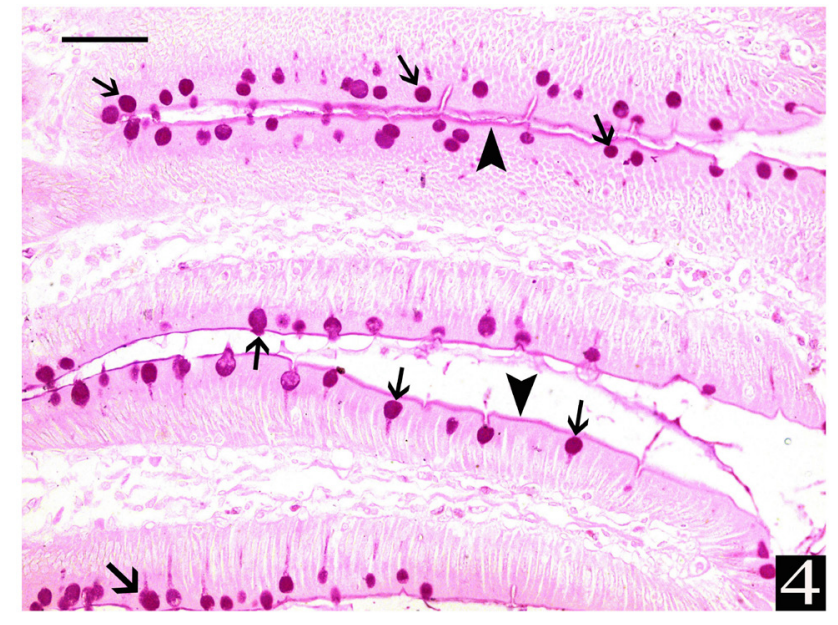

Fig. 4: A photomicrograph of a section in the duodenal mucosa of an adult albino rat from the control group showing an intense PAS positive reaction in the apical part of many goblet cells (arrow) and the brush border over the villi (arrow head). (PAS X400; Scale bar $=50 \mu \mathrm{m})$

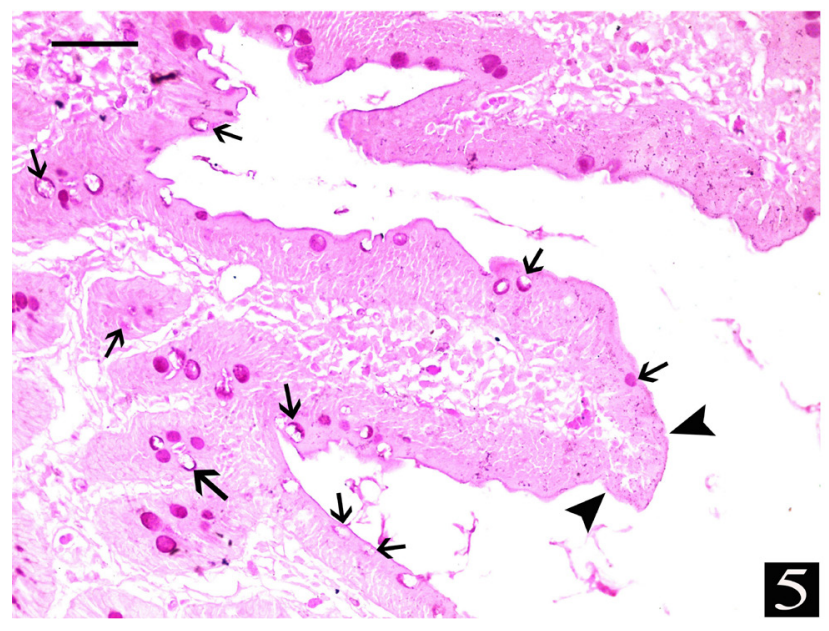

Fig. 5: A photomicrograph of a section in the duodenal mucosa of an adult albino rat from the Fosamax-treated group (group III) showing a weak PAS positive reaction in the apical part of many goblet cells (arrow) and the brush border (arrow head). (PAS X400; Scale bar $=50 \mu \mathrm{m})$

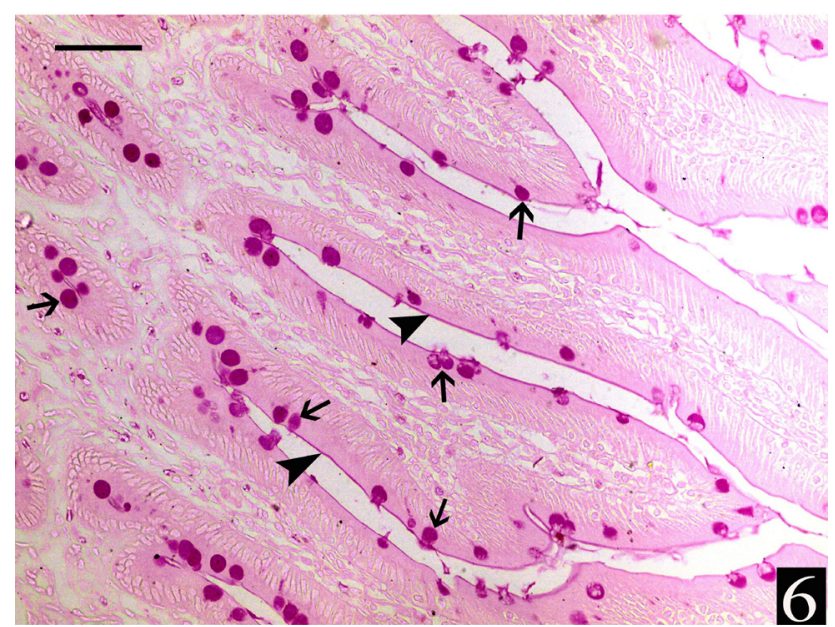

Fig. 6: A photomicrograph of a section in the duodenal mucosa of an adult albino rat from the Fosamax and $\mathrm{N}$ sativa oil-treated group (group IV) showing a moderate PAS positive reaction in the apical part of some goblet cells (arrow) and the brush border (arrow head). (PAS X400; Scale bar $=50 \mu \mathrm{m})$

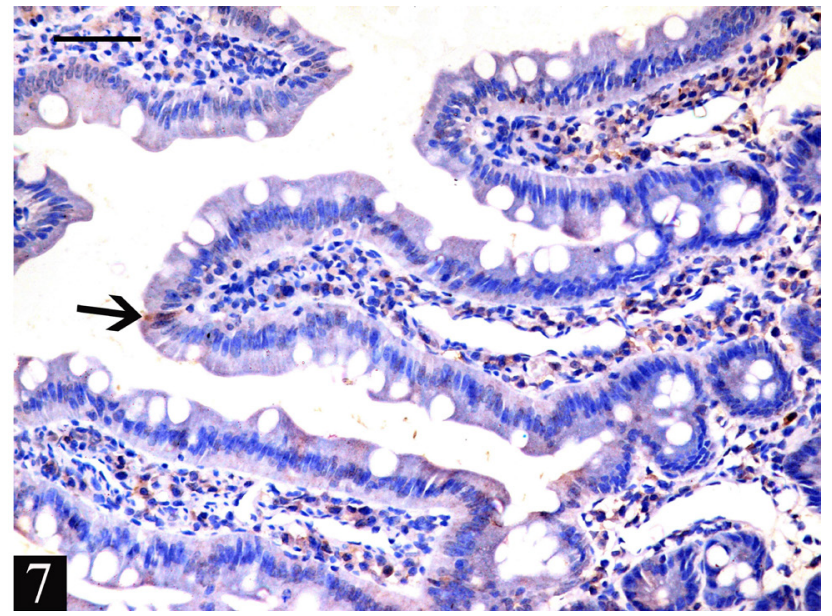

Fig. 7: A photomicrograph of a section in the duodenal mucosa of an adult albino rat from the control group showing a weak positive brown nuclear and/or perinuclear immunoreaction for nuclear factor $\kappa \mathrm{B}(\mathrm{NF}-\kappa \mathrm{B})$ in a few epithelial cells (arrow). (NF- $\mathrm{KB}$ immunostaining, X 400; Scale bar $=50 \mu \mathrm{m})$

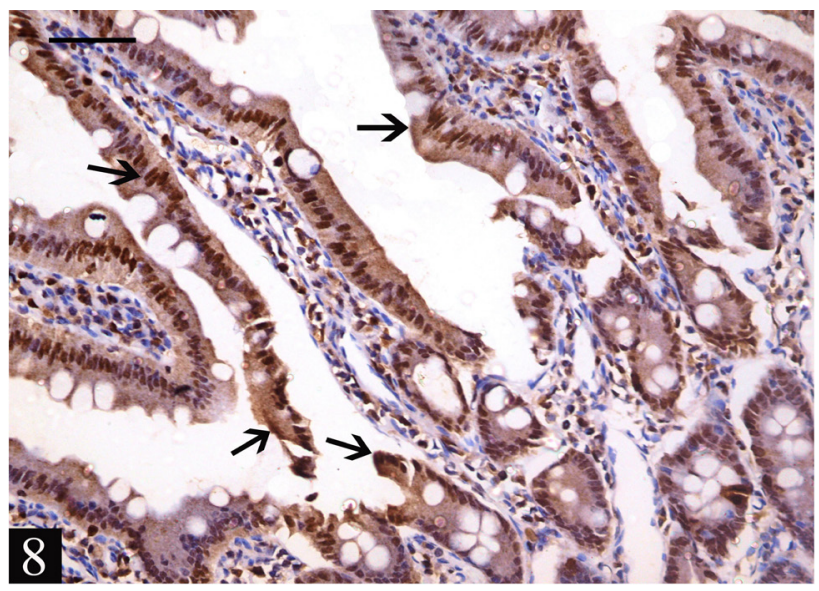

Fig. 8: A photomicrograph of a section in the duodenal mucosa of an adult albino rat from the Fosamax-treated group (group III) showing a strong positive brown nuclear and/or perinuclear immunoreaction for nuclear factor $\kappa \mathrm{B}(\mathrm{NF}-\kappa \mathrm{B})$ in many epithelial cells (arrow). (NF- $\kappa \mathrm{B}$ immunostaining, $\mathrm{X} 400$; Scale bar $=50 \mu \mathrm{m}$ )

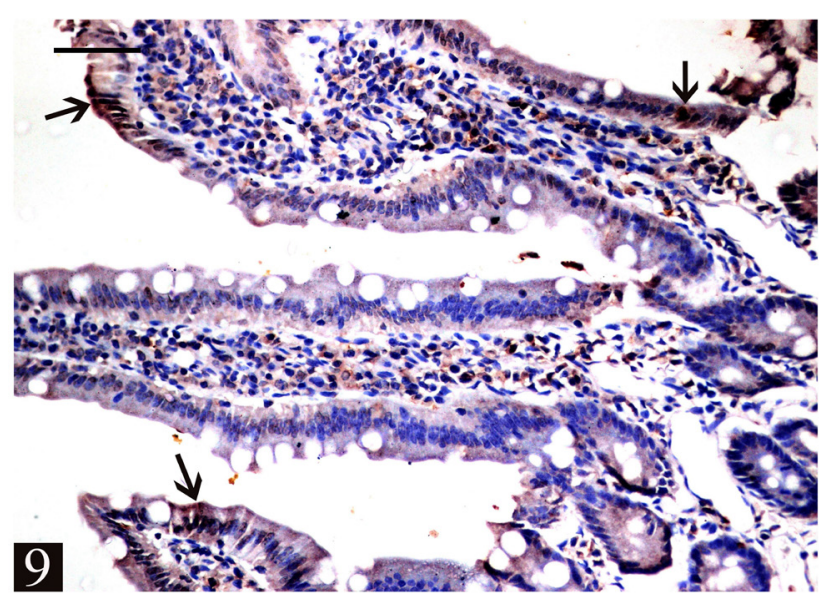

Fig. 9: A photomicrograph of a section in the duodenal mucosa of an adult albino rat from the Fosamax and $\mathrm{N}$ sativa oil-treated group (group IV) showing a moderate positive brown nuclear and/or perinuclear immunoreaction for nuclear factor $\kappa \mathrm{B}(\mathrm{NF}-\kappa \mathrm{B})$ in some epithelial cells (arrow). (NF- $\kappa$ B immunostaining, $\mathrm{X} 400$; Scale bar $=50 \mu \mathrm{m})$ 


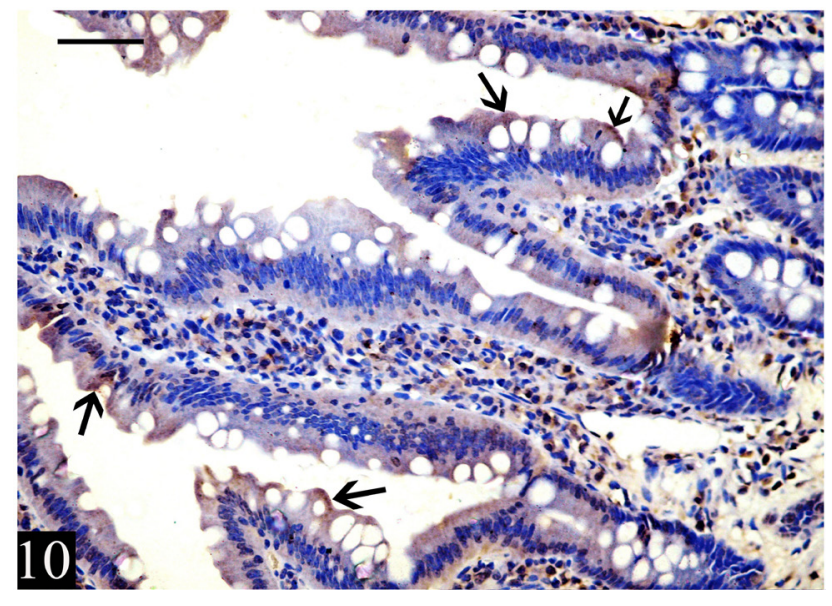

Fig. 10: A photomicrograph of a section in the duodenal mucosa of an adult albino rat from the control group showing a weak positive brown cytoplasmic COX-2 immunoexpression in a few epithelial cells (arrow). (COX-2 immunostaining, $\times 400$; scale bar $=50 \mu \mathrm{m})$

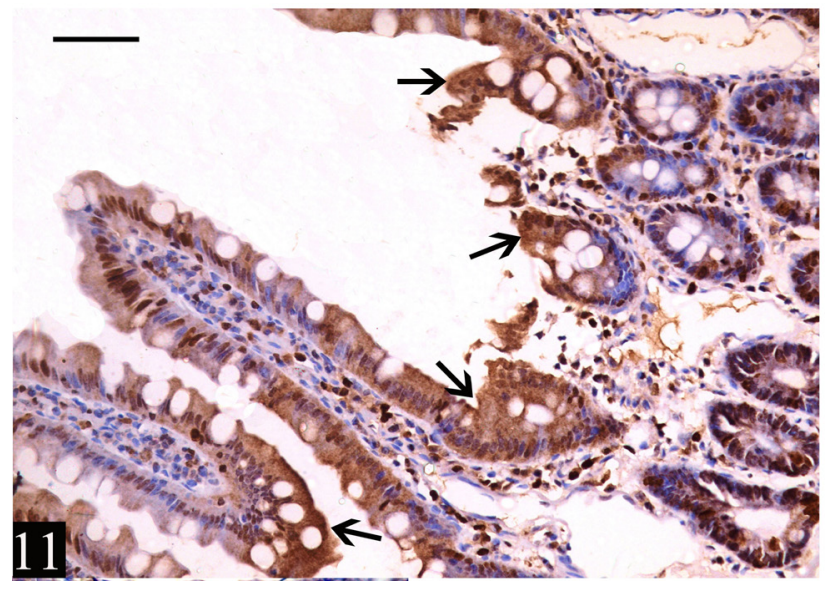

Fig. 11: A photomicrograph of a section in the duodenal mucosa of an adult albino rat from the Fosamax-treated group (group III) showing a strong positive brown cytoplasmic and/or nuclear immunoreaction for COX-2 in many epithelial cells (arrow). (COX-2 immunostaining, $\times 400$; scale bar $=50 \mu \mathrm{m})$

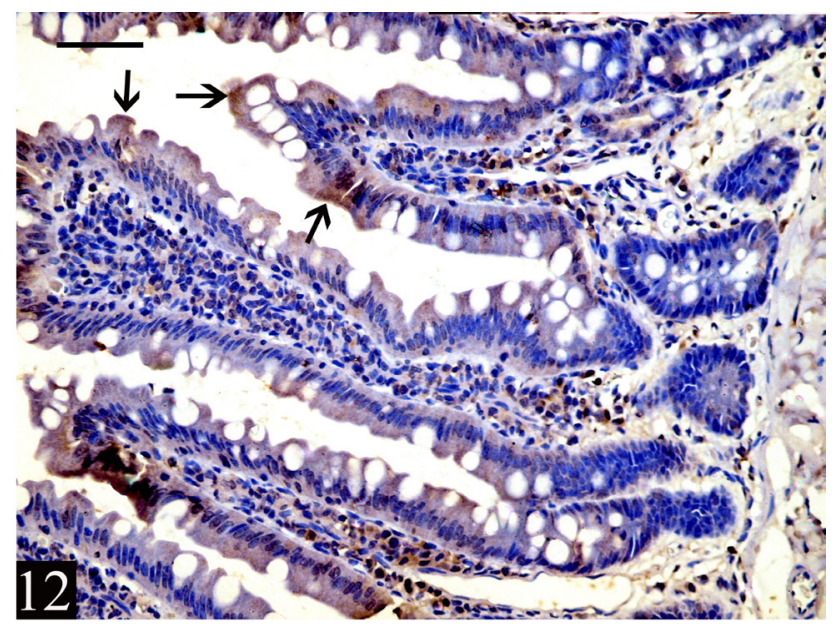

Fig. 12: A photomicrograph of a section in the duodenal mucosa of an adult albino rat from the Fosamax and $\mathrm{N}$ sativa oil-treated group (group IV) showing a moderate positive brown cytoplasmic and/or nuclear immunoreaction for COX-2 in some epithelial cells (arrow). (COX-2 immunostaining, $\times 400$; scale bar $=50 \mu \mathrm{m}$ )

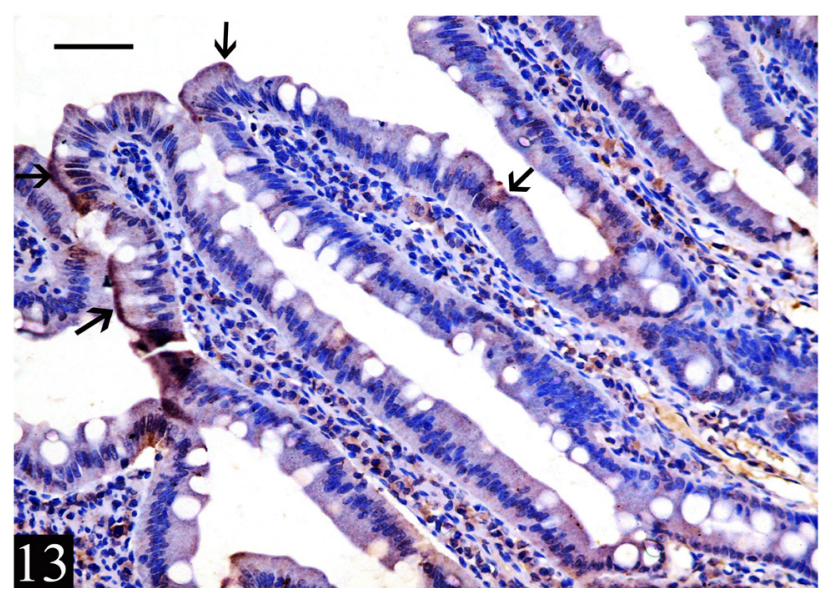

Fig. 13: A photomicrograph of a section in the duodenal mucosa of an adult albino rat from the control group showing a strong positive brown cytoplasmic Bcl-2 immunoexpression in the epithelial cells (arrow). (Bcl2 immunostaining, $\times 400$; scale bar $=50 \mu \mathrm{m}$ )

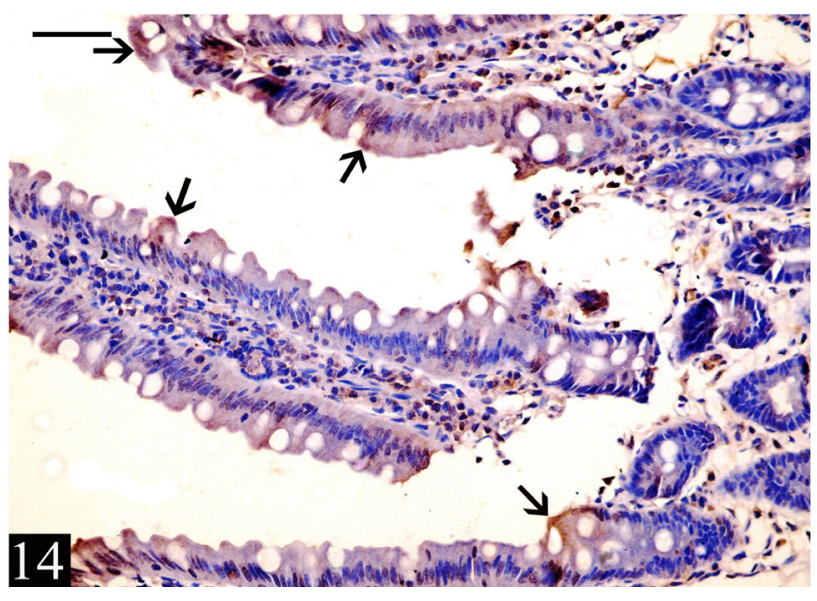

Fig. 14: A photomicrograph of a section in the duodenal mucosa of an adult albino rat from the Fosamax-treated group (group III) showing a weak positive brown cytoplasmic Bcl-2 immunoexpression in many epithelial cells (arrow). (COX-2 immunostaining, $\times 400$; scale bar $=50 \mu \mathrm{m})$

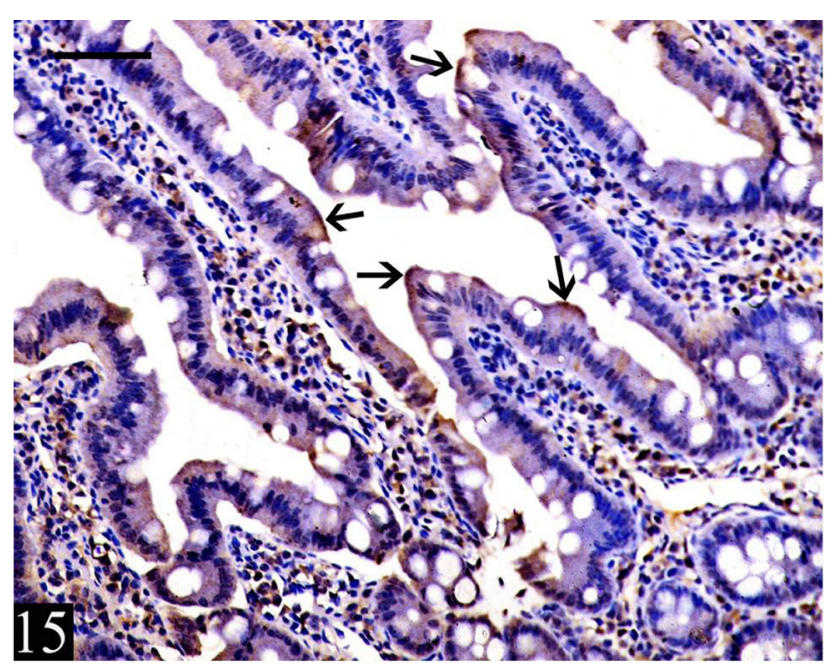

Fig. 15: A photomicrograph of a section in the duodenal mucosa of an adult albino rat from the Fosamax and $\mathrm{N}$ sativa oil-treated group (group IV) showing a moderate positive brown cytoplasmic Bcl-2 immunoexpression in some epithelial cells (arrow). (Bcl-2 immunostaining, $\times 400$; scale bar $=50 \mu \mathrm{m})$ 


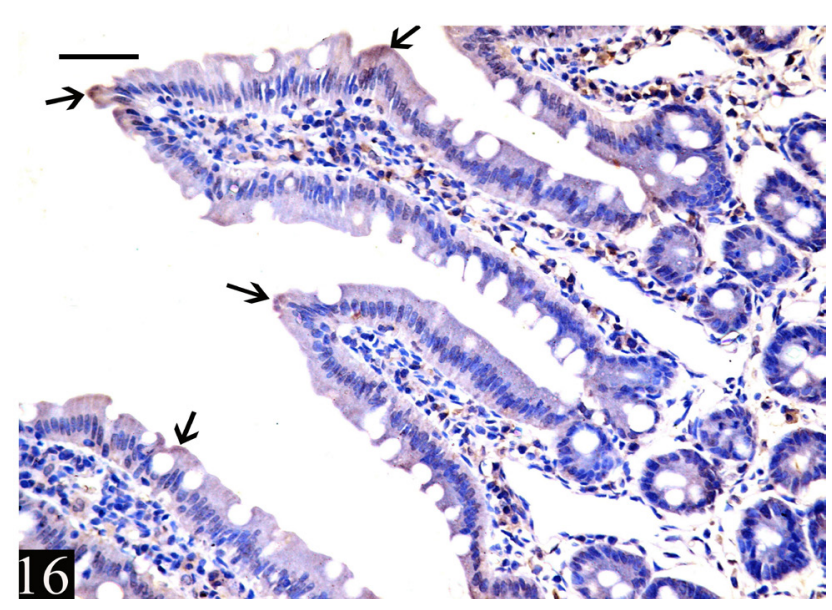

Fig. 16: A photomicrograph of a section in the duodenal mucosa of an adult albino rat from the control group showing a weak positive brown cytoplasmic and/or nuclear immunoreaction for Bax in a few epithelial cells (arrow). (Bax immunostaining, $\times 400$; scale bar $=50 \mu \mathrm{m}$ )

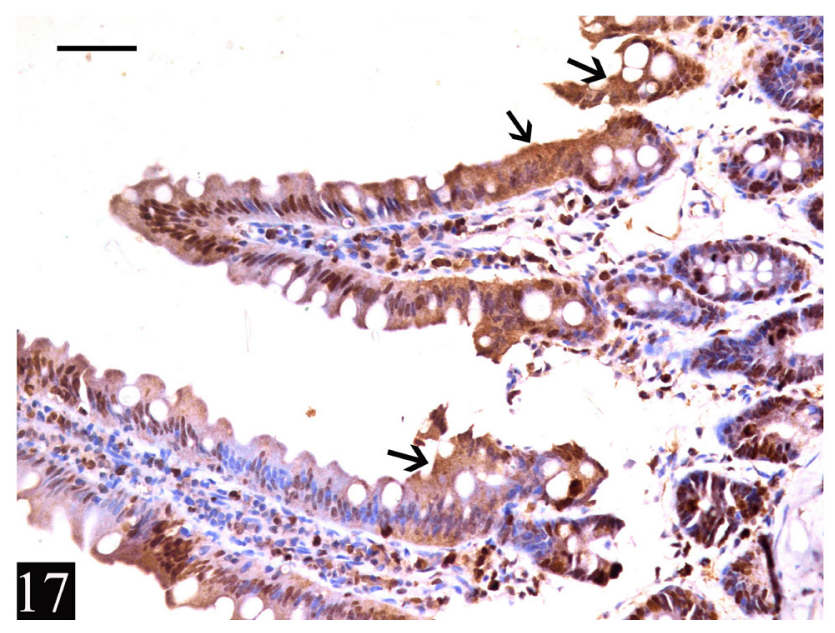

Fig. 17: A photomicrograph of a section in the duodenal mucosa of an adult albino rat from the Fosamax-treated group (group III) showing a strong positive brown cytoplasmic and/or nuclear immunoreaction for Bax in many epithelial cells (arrow). (Bax immunostaining, $\times 400$; scale bar $=50 \mu \mathrm{m})$

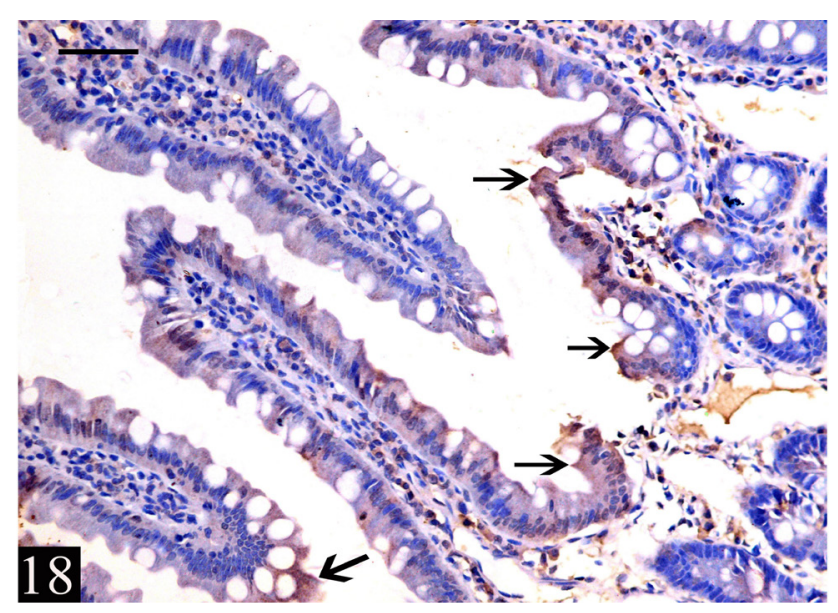

Fig. 18: A photomicrograph of a section in the duodenal mucosa of an adult albino rat from the Fosamax and $\mathrm{N}$ sativa oil-treated group (group IV) showing a moderate positive brown cytoplasmic and/or nuclear immunoreaction for Bax in some epithelial cells (arrow). (Bax immunostaining, $\times 400$; scale bar $=50 \mu \mathrm{m}$ )

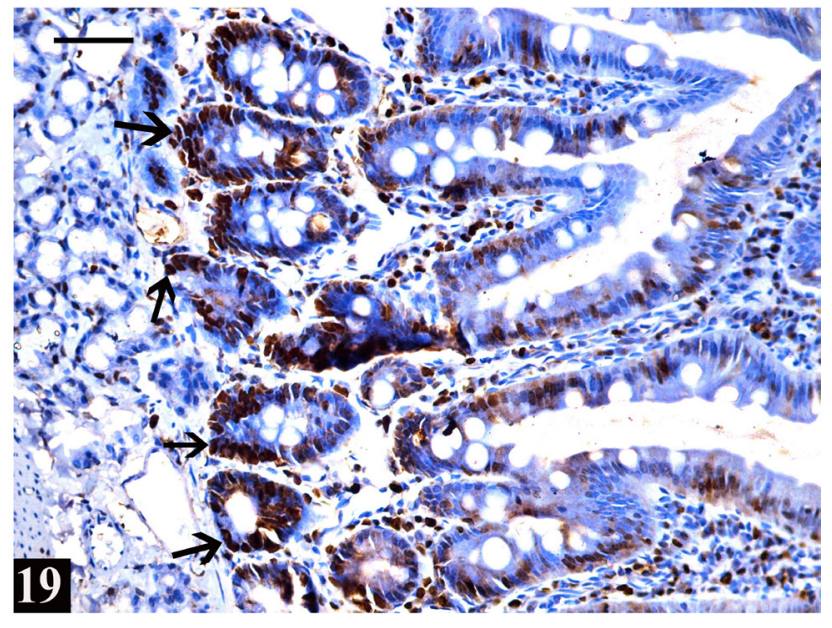

Fig. 19: A photomicrograph of a section in the duodenal mucosa of an adult albino rat from the control group showing a strong positive nuclear immunoreaction for Ki67 in the epithelial cell of the crypts (arrow). (Ki67 immunostaining, X 400; Scale bar $=50 \mu \mathrm{m}$ )

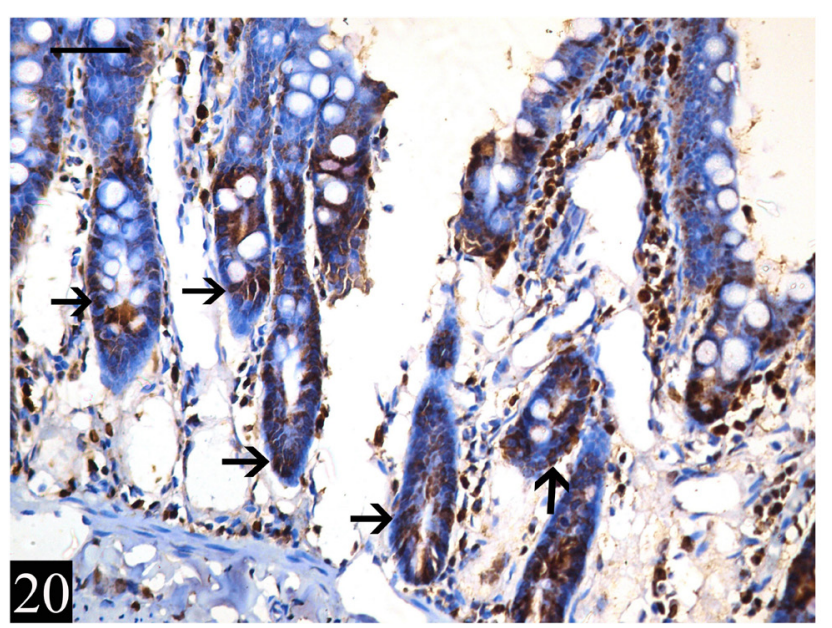

Fig. 20: A photomicrograph of a section in the duodenal mucosa of an adult albino rat from the Fosamax-treated group (group III) showing a weak positive nuclear immunoreaction for Ki67 in many crypt cells (arrow). (Ki67 immunostaining, X 400; Scale bar $=50 \mu \mathrm{m}$ )

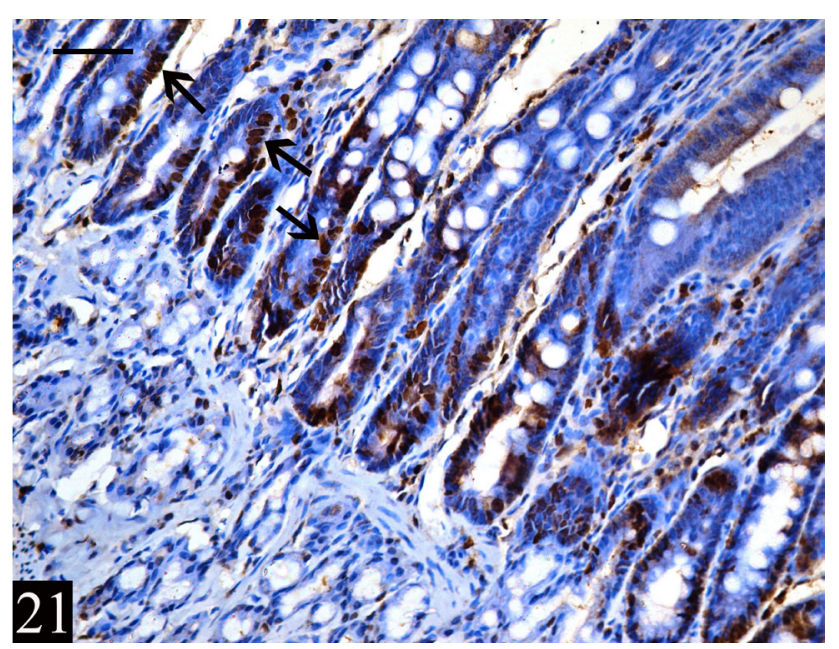

Fig. 21: A photomicrograph of a section in the duodenal mucosa of an adult albino rat from the Fosamax and N sativa oil-treated group (group IV) showing a moderate positive nuclear immunoreaction for Ki67 in some crypt cells (arrow). (Ki67 immunostaining, X 400; Scale bar $=$ $50 \mu \mathrm{m})$ 
Table 1: summarizes the mean thickness of the duodenal mucosa, villi height, crypt depth ( $\mu \mathrm{m})$ and goblet cell number in different groups. Data were expressed as mean $\pm \mathrm{SD}$

\begin{tabular}{|c|c|c|c|c|}
\hline Parameters & Group I & Group II & Group III & Group IV \\
\hline Mean duodenal mucosal thickness $(\mu \mathrm{m})$ & $933.5 \pm 36.9$ & $926.6 \pm 27.6$ & $646.4 \pm 87.3^{*}$ & $896.2 \pm 54$ \\
\hline Mean villi height $(\mu \mathrm{m})$ & $622.3 \pm 24.6$ & $617.8 \pm 18.4$ & $431.0 \pm 58.2^{*}$ & $597.4 \pm 36$ \\
\hline Mean crypt depth $(\mu \mathrm{m})$ & $211.2 \pm 12.3$ & $208.88 \pm 9.19$ & $121.1 \pm 26.9^{*}$ & $199.3 \pm 17.2$ \\
\hline Mean goblet cell number & $69.1 \pm 2.77$ & $69.3 \pm 2.16$ & $49.3 \pm 4.42^{*}$ & $66.6 \pm 2.55$ \\
\hline
\end{tabular}

$* P<0.05$ is significant versus control (group I).

Table 2: summarizes the mean area $\%$ of $\mathrm{NF}-\kappa \mathrm{B}, \mathrm{COX}-2$ and $\mathrm{Bcl} 2$ immunoreaction; the mean AI and PI; and the mean area percentage of PAS positive reaction for all groups. Data were expressed as mean $\pm \mathrm{SD}$

\begin{tabular}{lcccc}
\hline Parameters & Groups & Group I & Group II & Group III \\
\hline Mean area percentage of PAS positive reaction & $15.218 \pm 0.702$ & $15.436 \pm 0.714$ & $10.559 \pm 0.735^{*}$ & $14.639 \pm 0.510$ \\
Mean area \% of NF-kB & $6.216 \pm 0.705$ & $6.12 \pm 0.805$ & $20.17 \pm 1.27^{*}$ & $6.807 \pm 0.484$ \\
Mean area \% of COX-2 & $13.932 \pm 0.492$ & $13.928 \pm 0.634$ & $29.737 \pm 0.968^{*}$ & $14.412 \pm 0.563$ \\
Mean area \% of Bcl2 & $16.73 \pm 0.815$ & $16.887 \pm 0.851$ & $15.032 \pm 0.754^{*}$ & $16.043 \pm 0.639$ \\
Mean apoptotic index (\%) & $12 \pm 1.49$ & $11.9 \pm 1.37$ & $30.1 \pm 2.33^{*}$ & $13.1 \pm 0.738$ \\
Mean proliferative index (\%) & $76 \pm 3.77$ & $76.58 \pm 3.77$ & $59 \pm 2.52^{*}$ & $73.82 \pm 1.47$ \\
\hline
\end{tabular}

$* P<0.05$ is significant versus control (group I).

\section{DISCUSSION}

Fosamax is one of the most widely used antiosteolytic drugsinthe treatmentofmanybone disorders as osteoporosis. Despite its broad effectiveness, its gastrointestinal toxicity has been reported in many studies ${ }^{[4,5]}$. This has drawn attention towards new possible pathomechanisms that might be involved in the development of gastrointestinal toxicity, where targeting them could be promising for prevention of such toxicity.

Many studies have reported the anti-inflammatory and antioxidant effects of $\mathrm{N}$ sativa oil. Moreover, it is essential for the treatment of many gastrointestinal disorders involving the mucosa ${ }^{[14,15]}$. Accordingly, this research aimed to study the effect of Fosamax on the histological structure of the duodenal mucosa in adult male albino rats and to evaluate the possible protective role of nigella sativa oil using different histological and immunohistochemical techniques.

After reviewing the light microscopic results of this study, it could be demonstrated that treatment with Fosamax has altered the histological structure of the duodenal mucosa and caused marked destruction of some intestinal villi and crypts with sloughing of their epithelial cells. The remaining epithelial cells were vacuolated and degenerated having pyknotic nuclei. In addition, there was mucosal atrophy with reduced goblet cell number as demonstrated by the morphometric results of the present study which revealed a statistically significant decrease in the duodenal mucosal thickness, villi length and crypt depth. These results were consistent with the clinical results of some authors ${ }^{[4,7,24]}$ who reported many cases having gastrointestinal adverse effects associated with bisphosphonate treatment. Moreover, such duodenal mucosal structural changes were consistent with the findings of other researchers who attributed these changes to local irritation due to prolonged local mucosal exposure to alendronate which is the active ingredient of Fosamax leading to erosive or ulcerative mucosal damage with inflammation ${ }^{[9,25,26]}$.

The mechanism of alendronate-induced mucosal damage is by a direct oxidative damage, or by an indirect oxidative damage through induction of neutrophil infiltration. The activated and migrating neutrophils induced by alendronate are a potential source of oxygen metabolites that can induce mucosal injury. Previous data revealed that the toxic metabolites that participate in the alendronate-induced mucosal damage are mainly $\mathrm{H}_{2} \mathrm{O}_{2}$, $\mathrm{OH}+$, peroxynitrite, hypochlorite and lipid peroxyl radicals, which can severely disrupt cell membrane function leading to DNA damage and cell death in the gastrointestinal mucosa. Moreover, alendronate induces glutathione) an important intracellular antioxidant) depletion in the mucosa due to mitochondrial damage. Lipid peroxidation induced by reactive oxygen metabolites and glutathione depletion is believed to be an important cause of gastrointestinal mucosal damage. It has been reported that at $\mathrm{pH}<2$, alendronate is converted to alendronic acid, which is more irritating to mucosa than the alendronate ${ }^{[9,27]}$. Since in the present work, Fosamax was administered orally in fasted rats, it seems likely that the mucosal damage is due to the direct irritating effect of alendronate in its acid form.

In addition, alendronate induces TNF- $\alpha$ and IL-1 $\beta$ response and pro-inflammatory cytokines in the mucosa 
resulting in inflammation, subepithelial edema and sloughing of the epithelium or ulcer formation. Moreover, when alendronate is applied to the mucosa, it decreases trans-mucosal potential difference which is suggestive of a direct disruption of the surface epithelial cells ${ }^{[27]}$.

In the present study, marked depletion of mucus secretion in the duodenal mucosa of Fosamax-treated group occurred, as evidenced by marked depletion of PAS-positive material. This was attributed to the massive mucosal damage and exfoliation of the epithelial cells. This finding was in accordance with other authors who reported that the inhibitory effect of alendronate on mucosal mucus secretion may be one of the important factors in the mucosal injury ${ }^{[27]}$.

Upon immunohistochemical examination of NF$\kappa \mathrm{B}$ and $\mathrm{COX}-2$ expression, a significant increase was detected in the duodenal mucosa of Fosamax-treated group in comparison with the control group, thus strongly suggesting the involvement of the NF- $\mathrm{KB}$ signaling pathway in the injurious action of Fosamax. This comes in accordance with the work of others documenting the up-regulation of NF- $\kappa \mathrm{B}$ and the proinflammatory factor COX-2 in the gastric mucosa of alendronate-treated rats leading to mucosal inflammation ${ }^{[27,28]}$. NF- $\kappa B$ is a nucleoprotein that is normally found in an inactive form in the cytoplasm. Following activation, it quickly translocates from the cytoplasm to the nucleus to bind to their specific $\kappa \mathrm{B}$ sites, allowing various target gene expressions to be induced with subsequent pro-inflammatory consequences leading to cell and tissue damage. Cyclooxygenase-2 (COX-2)is induced predominantly during inflammation. COX-2 mRNA and protein in inflamed tissues are mainly located in the inflammatory cells but are also expressed in endothelial cells, fibroblast-like cells, and epithelial cells. It is generally expressed in the cytoplasm. However, it may be accumulated in the nucleus as a transcriptional factor to regulate gene expression. The induction of COX-2 is thought to be due to activating NF- $\kappa \mathrm{B}$ and its translocation to the nucleus where it can then bind on the COX-2 gene inducing its synthesis. COX-2 is considered as a main mediator of inflammation as it catalyzes the synthesis of pro-inflammatory prostaglandins, in particular prostaglandin $\mathrm{E} 22^{[29,30]}$.

The results of the present work could demonstrate that Fosamax induced apoptosis in the epithelium as demonstrated by the histological results that showed pyknotic nuclei of the epithelial cells that were interpreted as apoptosis by some authors ${ }^{[31]}$. In addition, the immunohistochemical results of the present work could reveal that Fosamax induced apoptosis in the epithelium through reduced Bcl-2 expression and increased Bax expression in Fosamax-treated group as compared to control group. These immunohistochemical findings were consistent with the findings of previous study which reported that apoptosis was involved in alendronateinduced cytotoxicity through increased expression of the pro-apoptotic protein, Bax and decreased expression of the anti-apoptotic protein, Bcl-2 ${ }^{[32]}$. Additionally, other studies supported that bisphosphonates decrease cell viability, migration ability, and increase apoptosis rate in the oral $\operatorname{mucosa}^{[33,34,35,36]}$.

$\mathrm{Bcl} 2$ is an anti-apoptotic protein that belongs to $\mathrm{Bcl}-2$ family. Overexpression of Bcl-2 enhances cell survival and differentiation and suppresses apoptosis. In cells subjected to apoptosis-inducing stimuli, $\mathrm{Bcl} 2$ protein expression is significantly reduced and is associated with increased level of the pro-apoptotic protein, Bax. The increased Bax/Bcl2 ratio results in cytochrome-c release from mitochondria triggering cell death by apoptosis ${ }^{[37]}$. Moreover, the intense nuclear localization of Bax can influence the ion channels across the nuclear membrane leading to apoptosis ${ }^{[38]}$. Bisphosphonates were accepted as potential toxins and extrinsic stimuli for apoptosis ${ }^{[34]}$.

The present results could demonstrate that Fosamax decreased the epithelial cells proliferation as demonstrated by the immunohistochemical results that showed a statistically significant decrease in Ki67 expression (Ki67 proliferative index) in the duodenal mucosa of Fosamaxtreated group compared to control group. This finding was consistent with the finding of other researchers who reported that alendronate inhibits proliferation of human gingival fibroblasts in a dose- and time dependent manner. The authors reported that alendronate has cytotoxic effects which causes significant changes in the proliferative index of their in vitro study ${ }^{[34]}$. It is well known that the mesenchymal stem cells (MSCs) play important roles in postnatal tissue development, tissue repair, and disease modification. Alendronate may have a negative impact on these roles of stem cells. The reduced cell proliferation by alendronate was accompanied with increased sub-G1 phase as an apoptosis indicator in the normal cell cycle ${ }^{[32]}$.

At the protective level, $\mathrm{N}$ sativa oil was introduced to examine its probable role in alleviating the duodenal mucosal structural changes induced by Fosamax. Results from this study clearly demonstrated that $\mathrm{N}$ sativa oil offered an evident improvement in the duodenal mucosal structural changes. Similar results were reported in other studies which demonstrated the protective effect of $\mathrm{N}$ sativa oil against gastric mucosal injury, improvement in the mucosal structure with decreased epithelial damage and improvement of the mucous secretion ${ }^{[14,39]}$. These results were also in accordance with another study in which $\mathrm{N}$ sativa oil exerted a potent protective effect against jejunal mucosal injury in rats ${ }^{[40]}$.

This could be attributed to the antioxidant capacity of $\mathrm{N}$ sativa oil as many studies established that $\mathrm{N}$ sativa oil enhanced the antioxidant defense mechanisms and reduced the oxidative stress, in addition to its free-radical scavenger capacity. This antioxidant capacity of the $\mathrm{N}$ sativa oil was attributed to its thymoquinone constituent which could antagonize the increased lipid peroxidation and in turn stabilize the integrity of the cellular membranes. Moreover, it could inhibit glutathione depletion; normalize the activity of antioxidant enzymes and improve the mitochondrial function ${ }^{[13]}$. 
In this study, treatment with $\mathrm{N}$ sativa oil decreased the inflammatory cellular infiltration. $\mathrm{N}$ sativa oil has a modulatory effect on the inflammatory response ${ }^{[15]}$ by reducing the cellular infiltration and secretion of inflammatory cytokine and improving intestinal barrier function ${ }^{[13,41]}$.This anti-inflammatory effect has been attributed to its inhibitory effect on the NF$\kappa \mathrm{B}$ and cyclooxygenase-2 (COX-2) pathway and the proinflammatory mediators such as - IL-1 $\beta$, IL-6, TNF- $\alpha$, IFN- $\gamma$, and PGE2 ${ }^{[42]}$.

In addition, $\mathrm{N}$ sativa oil was found to be beneficial in ameliorating the degree of apoptotic cell death. Its antiapoptotic effect could be probably mediated through the upregulation of Bcl-2 protein and suppression of Bax protein expression as observed from the immunohistochemical results of the current work. Though, other investigators explained the anti-apoptotic activity of $\mathrm{N}$ sativa oil to be through down regulation of caspase-3 expression ${ }^{[43]}$.

In addition, the present study revealed improved Ki67 proliferative index of the epithelium in Fosamax and $\mathrm{N}$ sativa oil-treated group. Similar results were reported in a previous study which revealed that $\mathrm{N}$ sativa oil stimulates the proliferation of beta cells of the pancreas in diabetes mellitus ${ }^{[44]}$. Another study reported that $\mathrm{N}$ sativa oil enhanced the therapeutic potential of MSCs and triggered MSCs homing to the damaged site. It was observed that combined $\mathrm{N}$ sativa oil /MSCs therapy provided more beneficial tissue repair comparable to MSCs alone ${ }^{[45]}$. Also, $\mathrm{N}$ sativa oil has an anabolic effect on MSCs to stimulate their differentiation ${ }^{[46]}$. So, it could help in the repair of the damaged duodenal mucosal tissue by stimulating the proliferation of the intestinal stem cells.

In conclusion, Fosamax induced structural changes in the duodenal mucosa of albino rats. It induced mucosal inflammation in addition to its apoptotic and anti-proliferative effect on the epithelium. The present work suggests the possible participation of the $\mathrm{NF}-\kappa \mathrm{B} / \mathrm{COX}-2$ signaling pathway in the Fosamax-induced duodenal mucosal damage and subsequently the promising protective effect of $\mathrm{N}$ sativa oil that could be exerted by intercepting that particular pathway resulting in a strong anti-inflammatory response in addition to its potent antioxidative and anti-apoptotic properties. Therefore, $\mathrm{N}$ sativa oil may be a useful therapeutic agent for the patient undergoing treatment with Fosamax to minimize the duodenal mucosal injury.

\section{CONFLICT OF INTEREST}

There are no conflict of interest.

\section{REFERENCES}

1. Osman AS, Labib DAA, Omar AI: Do acid suppressive drugs (pantoprazole and ranitidine) attenuate the protective effect of alendronate in estrogen-deficient osteoporotic rats? The Egyptian Rheumatologist (2018) 40:99-106.
2. Salazar M, Hernandes L, Ramos AL, Salazar B, Micheletti KR, Paranhos LR, de Mendonc MR, Cuoghi OA: Effect of alendronate sodium on tooth movement in ovariectomized rats. Archives of oral biology (2015) 6 0: $776-781$.

3. Brandi ML and Black D: A drinkable formulation of alendronate: potential to increase compliance and decrease upper GI irritation. Clinical Cases in Mineral and Bone Metabolism (2013) 10(3): 187-190.

4. Modi A, Siris ES, Fan CS, Sajjan S: Gastrointestinal events among patients initiating osteoporosis therapy: A retrospective administrative claims database analysis. Clinical Therapeutics (2015) 37 (6): 1228-1234.

5. Modi A, Fan CS, Tang J, Weaver JP, Sajjan S: Association of gastrointestinal events with osteoporosis treatment initiation and treatment compliance in Germany: An observational study. Bone Reports (2016) 5: 208-213.

6. Vella V: Drug-induced peptic ulcer disease. Journal of the Malta College of Pharmacy Practice (2005)10:15-19.

7. Peng YL, Hu HY, Luo JC, Huo MC, Lin HC, Lee FY: Alendronate, a bisphosphomate, increased upper and lower gastrointestinal bleeding: risk factor analysis from a nationwide populationbased study. Osteoporos Int (2014) 25(5): 1617-23

8. Lowe CE, Depew TW, Vanner SJ, Paterson WG and Meddings JB: Upper gastrointestinal toxicity of alendronate. American Journal of Gastroenterology (2000) 95: 634-640.

9. Íseri SÖ, Sqener G, Yüksel M, Contuk G, Çetinel S, Gedik N, Yegen BÇ: Ghrelin against alendronateinduced gastric damage in rats. Journal of Endocrinology (2005) 187: 399-406.

10. Stanimirov $\mathrm{P}$ and Petkova M: Bisphosphonate related mucositis (BRM): A case report. J of IMAB (2017) 23(1): 1487-1489.

11. Finn D, Field A, Rajlawat B, Randall C: Oral mucosal ulceration induced by alendronic acid: a case series. Dental Updates (2018) 45(1): 38-42.

12. Hasan MN, Khan RA, Nasiruddin M, Khan AA Protective effect of nigella sativa against aspirin induced gastric damage in rats. Int J Pharm Pharm Sci, (2014) 6(5): 275-278.

13. Shakeri F, Gholamnezhad Z, Mégarbane B, Rezaee R, Boskabady MH: Gastrointestinal effects of Nigella sativa and its main constituent, thymoquinone: a review. Avicenna J Phytomed (2016) 6(1): 9-20. 
14. Mohammed SS, Naim MM, Mahmoud SH: Possible protective effect of nigella sativa oil against piroxicam-induced gastric mucosal damage in adult male albino rats (Light and Scanning Electron Microscopic Study). Egypt J Histo (2010) 33:127-139.

15. Emekli-Alturfan E, Yarat A, Tunali-Akbay T, Isik F, Yenidogan G, Sener G, Sehirli O, Pisiriciler R, Altintas A: Effect of black cumin (Nigella Sativa) seed oil on gastric tissue in experimental colitis. Adv Environ Biol (2011) 5:483-90.

16. Salim EI, Fukushima S: Chemopreventive potential of volatile oil from black cumin (Nigella sativa L.) seeds against rat colon carcinogenesis. Nutr cancer (2003) 45:195-202.

17. Isik F, Akbay TT, Yarat A, Genc Z, Pisiriciler R, Caliskan-AK E, Cetinel S, Altmtas A, Sener G: Protective effects of black cumin (Nigella sativa) oil on TNBS-induced experimental colitis in rats. Dig Dis Sci (2011) 56: 721-730.

18. Papamitsou T, Karachrysafi S, Toskas A, Dietrich E, Kostelidou A, Antonia S: Bisphosphonate's effect in hepatic rat cells: An electron microscopic study. Aristotle University Medical Journal (2016) 43(3): 7-11.

19. Gaertner DJ, Hallman TM, Hankenson FC, Batcherder MA: Anesthesia and analgesia for laboratory rodents. Anesthesia and analgesia in laboratory animals. 2 nd edition. Academic press, San Diego, CA. Boston. (2008): 239 -240.

20. Bancroft JD and Gamble M: Theory and practice of histological techniques. 6th edition, Elsevier health science. (2008): 126-127.

21. Kiernan JA: Histological and histochemical methods: Theory and practice. 3rd ed. ButterworthHeinemann: Oxford (2000) p. 320-90.

22. Ramos-Vara JA, Kiupel M, Baszler T, Bliven L, Brodersen B, Chelack B, West K, Czub S, Del Piero F, Dial S, Ehrhart EJ, Graham T, Manning L, Paulsen D and Valli VE: Suggested guidelines for immunohistochemical techniques in veterinary diagnostic laboratories. J Vet Diagn Invest (2008) 20: 393-413.

23. Dawson-Saunders B and Trapp R: Basic and clinical biostatics. 3rd ed., Lang Medical Book, McGrow Hill Medical Publishing Division. 2001; 161-218.

24. Marshall JK, Rainsford KD, James C, Hunt RH: A randomized controlled trial to assess alendronateassociated injury of the upper gastrointestinal tract. Aliment Pharmacol Ther (2000) 14: 1451-1457.
25. Lengfeld J, Buder-Bakhaya K, Goebeler M, Wobser M: Bisphosphonate-Mediated Oral Ulcers: A Rare Differential Diagnosis of Erosive Oral Lesions. Dermatology (2016) 232:117-121.

26. Mok JO, Jung $\mathrm{CH}$, Kim $\mathrm{CH}$, Ryu CB, Kim YJ, Kim SJ, Park HK, Suh KI, Yoo MH, Byun D: Endoscopic comparison of alendronate alone and the enteric-coated alendronate with calcitriol combination in postmenopausal Korean females. Korean J Intern Med (2013) 28:694-700.

27. Carvalho NS, Silva MM, Silva RO, Nicolau LD et al. Protective effects of simvastatin against alendronate-induced gastric mucosal injury in rats. Dig Dis Sci (2015) 61(2).

28. Magierowski M, Magierowska K, Szmyd J, Surmiak M, Sliwowski Z, Kwiecien S, Brzozowski T: Hydrogen Sulfide and Carbon Monoxide Protect Gastric Mucosa Compromised by Mild Stress Against Alendronate Injury. Dig Dis Sci (2016) 61:3176-3189.

29. Thanan R, Murata M, Ma N, Hammam O, Wishahi M, Leithy T, Hiraku Y, Oikawa S, Kawanishi S: Nuclear localization of COX02 in relation to the expression ofstemness markers in urinary bladder cancer. Mediators of Inflammation (2012) volume 2012, Article ID 165879:1-8.

30. Homaidan FR, Chakroun I, El-Sabban ME: Regulation of nuclear factor-kB in intestinal epithelial cells in a cell model of inflammation. Mediators of Inflammation (2003) 12(5): 277-283.

31. Theodora P, Stella F, Angeliki P, Eva-Maria D, Dimitris K, Alexandros T, Sofia K, Antonia S: Effect of alendronic acid on buccal mucosa. J Dent Oral Health (2018) 4(3): 1-6.

32. Pourgonabadi S, Ghorbani A, Tayarani Najarn Z, Mousavi SH. In vitro assessment of alendronate toxic and apoptotic effects on human dental pulp stem cells. Iran J Basic Med Sci (2018) 21: 905-910.

33. PabstAM, Ziebart T, Koch FP, Taylor KY,Al-Nawas $\mathrm{B}$, Walter $\mathrm{C}$. The influence of bisphosphonates on viability, migration, and apoptosis of human oral keratinocytes - in vitro study. Clin Oral Investig (2012)16(1):87-93.

34. Soydan SS, Araz K, Senel FV, Yurtcu E, Helvacioglu F, Dagdeviren A, Tekindal MA, Sahin F: Effects of alendronate and pamidronate on apoptosis and cell proliferation in cultured primary human gingival fibroblasts. Human and Experimental Toxicology (2015)34: 1-10. 
35. McLeod NM, Moutasim KA, Brennan PA, Thomas $\mathrm{G}$, Jenei V: In vitro Effect of Bisphosphonates on Oral Keratinocytes and Fibroblasts. J Oral Maxillofac Surg (2014)72: 503-509.

36. Allam E, Allen M, Chu TM, Ghoneima A, Jack Windsor L: In vivo effects of zoledronic acid on oral mucosal epithelial cells. Oral Dis (2011)17(3):291-297.

37. Qiao WL, Wang GM, Shi Y, Wu JX, Qi YJ, Zhang JF, Sun H, Yan CD: Differential expression of Bcl2 and Bax during gastric ischemia-reperfusion of rats. World J Gastroenterol (2011) 17(13): 1718-1724.

38. Mandal M, Adam L, Mendelson J, Kumar R: Nuclear targeting of Bax during apoptosis in human colorectal cancer cells. Oncogene (1998) 17:999-1007.

39. Bukar MA, Ishaya HB, Dibal NI, O. Attah MO: Gastroprotective effect of Nigella sativa seed on ethanol-induced gastric ulcer in rats. Libyan J Med Sci (2017)1:63-7.

40. Orhon ZN, Uzal C, Kanter M, et al. Protective effects of Nigella sativa on gamma radiationinduced jejunal mucosal damage in rats. Pathol Res Pract (2016) 212(5):437-443.
41. Al-Shaha OMS and Mohammed SA: Gastro protective effect of oil extract of nigella sativa seeds against aspirin-induced gastric ulcer in albino rats. Journal of Entomology and Zoology Studies (2017) 5(4): 725-732.

42. Islam MT, Guha B, Hosen S, Riaz TA, Shahadat S, Sousa L, Santos JV et al. Nigellalogy: A review on nigella sativa. MOJ Bioequiv Availab (2017) 3(6): 00056.

43. Shahroudi MJ, Mehri S, Hosseinzadeh $\mathrm{H}$ : Anti-aging effect of nigella sativa fixed oil on D-Galactose-induced aging in mice. Journal of Pharmacopuncture (2017)20(1):029-035.

44. Saleem U, Sabir S, Ahmad B: How nigella sativa seeds treat diabetes and ameliorate diabetes complications and safety studies: An over view. BJPR (2016) 14(3): 1-8.

45. Radwan RR and Mohamed HA: Nigella sativa oil modulates the therapeutic efficacy of mesenchymal stem cells against liver injury in irradiated rats. $\mathrm{J}$ Photochem Photobiol B (2018) 178: 447-456.

46. Mendi A: Nigella sativa oil could induce osteogenic differentiation of dental pulp mesenchymal stem cells: clinical nutrition for dentistry. Food and Health (2018) 4(1), 19-24. 


\section{الملخص العربى}

\section{ثأثير فوساماكس على الغثاء المخاطي للاثني عشر فى ذكور الجرذان البيضاء البالغة والوقاية المحتملة بواسطة زيت حبة البركة: دراسة هستولوجية و هستوكيميائية مناعية أميرة عدلى كساب}

قسم الهستولوجيا، كلية الطب، جامعة طنطا، مصر

المقدمة: فوساماكس، هو ثنائي الفوسفونيت عن طريق الفم، وهو الدواء الأكثر شيو عًا لعلاج أمر اض العظام المختلفة. ومع ذللك، يرتبط العلاج بالفوساماكس مع سمية الجهاز الهضمي التي تؤثر على الامنتال العلاج. وقد استخدمت حبة البركة وهو نبات عشبي موسمي بأمان كعلاج طبيعي في مصر. و لها دور مقترح في مكافحة العديد من اضطر ابات الجهاز الهضمي حيث أن لايها مجمو عة واسعة من الأنشطة الدو ائية. الهدف من البحث: يهدف هذا العمل إلى در اسة تأثير فوساماكس على التركيب النسيجي للغثاء المخاطي للاثني عشر للجرذان البيضاء ولتقييم الدور الوقائي المحتمل لزيت حبة البركة. مواد وطرق البحث: تم تقيم أربعين جرذاً من ذكور الجرذان البيضاء البالغة إلى أربع مجموعات متساوية: المجمو عة الضابطة، و المجموعة المعالجة بزيت حبة البركة (. Y ملجم / كجم)، و المجمو عة المعالجة بالفوساماكس (0 . . ملجم / كجم)، و المجموعة المعالجة بالفوساماكس وزيت حبة البركة معا. تم اعطاء الحيوانات هذه الجرعات بالفم مرة واحدة أسبو عيا لمدة سا أسبو عا. تم تجهيز عينات من الاثني عشر للفحص بالمجهر الضوئى. كما تم عمل صبغات هستوكيميائية مناعية بإستخدام أجسام ضد NF-кB, COX-2, Bcl-2, Bax, Ki67. النتائج: أظهرت عينات من الجرذان المعالجة بعقار فوساماكس انخفاض ذو دلالة إحصائية فى سمك الغشاء المخاطى للاثني عشر. كما ظهرت تجاويف في السيتوبلازم وبعض التغيرات فى انوية الخلايا الطلائية. كما لوحظ وجود بعض الخلايا وحيدة النواة. وقد أظهرت الدر اسة الهستوكيميائية المناعية زيادة ذات دلالة إحصائية في التفاعل المناعى لكل

من NF-kB, COX-2, Bax. و انخفاض ذو دلالة إحصائية في التفاعل المناعى لكل من Bcl-2, Ki67. في المقابل، فقد لوحظ تغير ات طفيفة فى الجرذان التى عولجت بالتز امن بكل من عقار فوساماكس و زيت حبة البركة مع وجود تغير ات ليست لها دلالة إحصائية فى التفاعلات المناعية. الاستتناج: عقار فوساماكس تسبب فى حدوث تغير ات تركيبية فى الغشاء المخاطي للاثني عشر للجرذان البيضاء البالغة التي يمكن أن تتحسن بالعلاج المصاحب بزيت حبة البركة. 